\title{
NEW JERSEY HISTORY AND RICHARD P. MCCORMICK
}

\author{
BY ROBERT G. SEWELL
}

The summer of 2005 brought unprecedented attention to the New Jersey historical and archival communities.In June, a cache of colonial period archival materials relating to New Jersey was to be auctioned at Christie's. There was a buzz throughout the New Jersey history community and a conviction that these documents should be publicly available in a state institution for researchers and the citizens of the state.It began when the prominent rare book and New Jerseyana book dealer Joseph J. Felcone brought this auction to the attention of Rutgers' Head of Special Collections Ronald L. Becker.Becker's first thought was to contact Richard P. McCormick, who had collaborated with Becker in the past when some extraordinary acquisitions came to his attention.Because the price for the colonial documents at Christie's was estimated to be several hundred thousand dollars, a case was made by Becker, McCormick, the New Jersey State Archives, and the New Jersey historical community to Acting Governor Richard E. Codey to see if special state funding could be used for the purchase. Codey found the money that enabled the State Archives to purchase this packet of treasures of early New Jersey history.

Richard P. McCormick, Rutgers professor emeritus, university historian, dean of Rutgers College, and scholar and teacher of American and New Jersey history, was one of the people most excited by this purchase. Joseph Klett's article herein reports McCormick's delight at reading the most prized acquisition from the purchase, the record book of East Jersey's proprietary governor, Robert Barclay (1648-1690) that is transcribed in full at the end of this volume. In his classic work, New Jersey from Colony to State, 1609-1789 (1964), McCormick comments on Barclay:

...the outstanding Scottish Quaker, [who] was made 


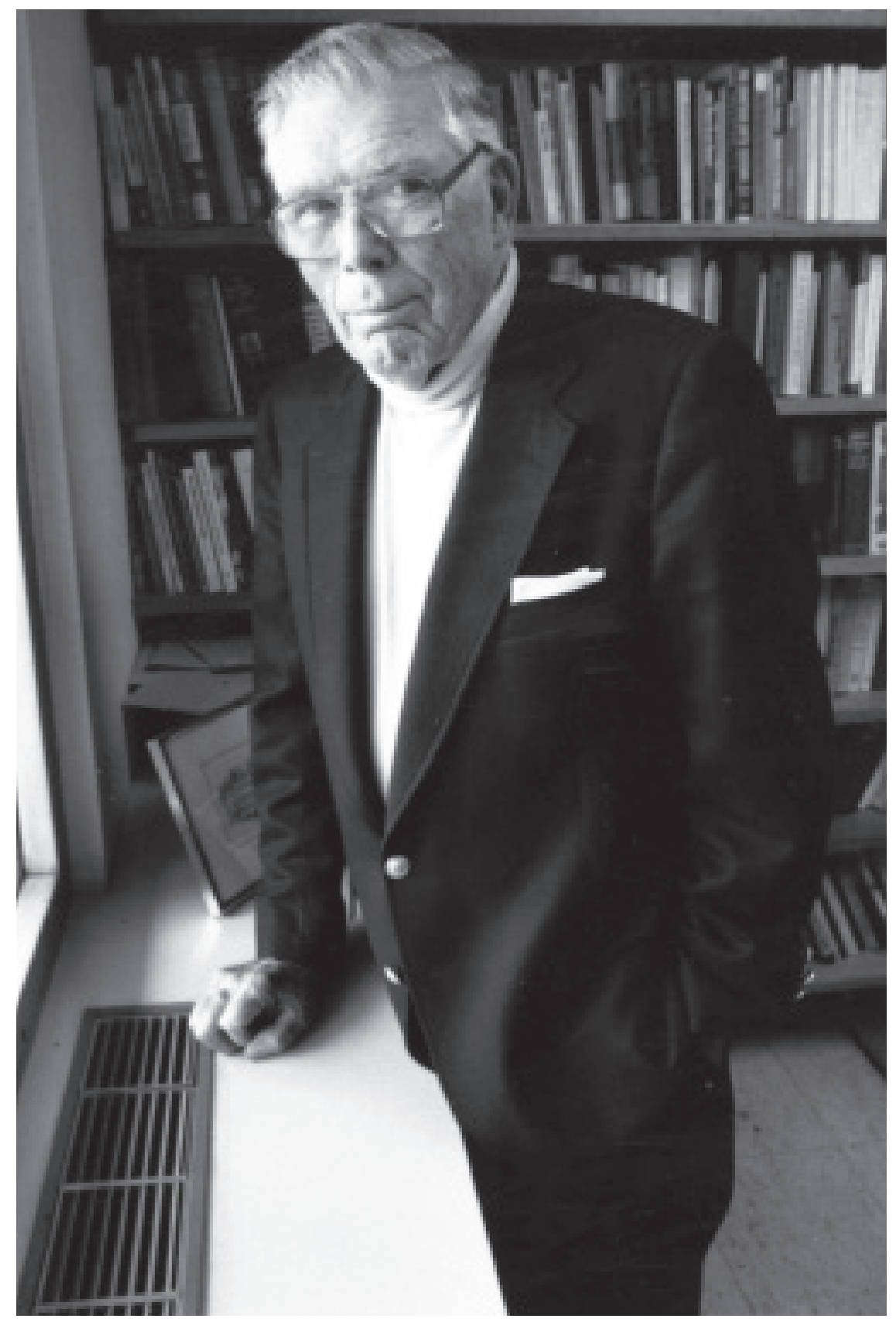

Figure 1.1 Richard P. McCormick (Photograph from Rutgers University Special Collection and University Archive 
governor of East Jersey. Barclay persuaded many influential Scots, among them the powerful Earls of Perth and Melfort, to purchase shares in the proprietorship and initiated a vigorous advertising campaign to encourage emigration to America.... [As a result of these efforts] Between 1683 and 1685 perhaps five hundred Scots of high and low estate arrived in the colony, most of whom settled in Middlesex, Monmouth, and Somerset counties where in time they came to exercise an influence out of all proportion to their numbers. ${ }^{1}$

At the time he wrote these words, McCormick, along with all other colonial historians, had no idea that these records of the East Jersey proprietors covering some of the years of this great influx of Scots were extant. The documents had been in private hands for hundreds of years.

At the opening of the September 27, 2005 exhibition of the newly purchased East Jersey materials held at Morven Museum and Gardens in Princeton, McCormick gave an address that captured his enthusiasm for both the historical value of the items as well as the importance of this extraordinary acquisition with state funds. His address is provided here:

What a glorious day! I feel honored at being invited to participate in this celebratory occasion. For our historical community, it is a day of thanksgiving. I know you will be as thrilled as I was, to see the previously inaccessible treasures that are exhibited upstairs.

No doubt you have read about the items in press accounts. Especially notable are the minutes of the meetings of the East Jersey Proprietors in London from 1682 to 1684 , the charming accounts of the seven early towns, the several crudely drafted but extremely informative maps. The authentic copies of our founding documents dating from 1664 are truly awesome. Your spines will tingle.

I have had an opportunity to scan the meticulously recorded minutebook. The Quakerproprietors, including William Penn, took their duties seriously. They met 41 
times in a little over two years after acquiring East Jersey from the heirs of Sir George Carteret in 1682.

They prepared instructions for their provincial officials, called for the return of Staten Island to their jurisdiction, made detailed plans for the development of Perth Amboy, and drafted a fanciful constitution, which they had the good sense not to enforce.

Recognizing that they were too remote from their colony to manage its affairs, they turned over full authority in 1684 to the proprietors or their proxies who were actually on the ground.

Take note that this was no ordinary acquisition. Admire the boldness of Karl Niederer, Joe Klett, Joe Felcone and their associates in daring to undertake the venture. Their vision was without precedent.

Applaud the enthusiastic support manifested by the hundreds of individuals and scores of historical societies who enlisted in the campaign. Pay homage to our public officials, led by the Secretary of State and the Acting Governor. They quickly grasped the importance of this enterprise and brought it to fruition.

Not least of all, give thanks that a funding source was discovered. I refer to the little known Public Record Preservation Fund that was established by the legislature in 2003.

These combined efforts, it seems to me, represent a general advance to a new level of achievement in state and local history programs in New Jersey. No longer are we laggards; we have become leaders.

We must continue to move forward with the confidence and vision that produced the result that we are celebrating today. ${ }^{2}$

The acquisition of these documents by the state of New Jersey, in a sense, capped McCormick's long involvement in New Jersey history and its documentation. In addition to his own numerous publications on New Jersey history, he was a public advocate and activist in the development and promotion 
of New Jersey history. Shortly after coming to Rutgers as a professor, he established in 1948 the Conference of New Jersey Historians that brought together interested parties from local and historical societies, many of the state colleges and universities, and public agencies like the state library and state museum. The conference laid the foundation for New Jersey history for decades to come, including the founding of the New Jersey Historical Commission and its book series, the revitalization of the New Jersey Historical Society, the establishment of the New Jersey Tercentenary Commission, and many other activities. Furthermore, as Michael Birkner notes in McCormick of Rutgers: Scholar, Teacher, Public Historian, "Little serious scholarship on New Jersey History was published by any New Jersey press between 1950 and 1980 without McCormick's imprimatur." ${ }^{3}$

In 1960 on behalf of the New Jersey Tercentenary Commission, McCormick traveled to Great Britain and Amsterdam in search of early unpublished records related to New Jersey and to arrange to make copies of them. This was deemed important for the Tercentenary Celebration in 1964 since there had been no systematic investigation of New Jersey materials in British repositories since the 1870s. In his Microfilm Report of Dr. Richard P. McCormick: Visit to Great Britain (1960), ${ }^{4}$ he describes the results of his efforts and gives an annotated list of the items he discovered and had copied. Having done this work forty-five years before made the 2005 acquisition of the East New Jersey Proprietors' minutes especially meaningful to him.

I wrote Professor McCormick when we decided to do this special issue on the Minutes of the meetings of the East Jersey proprietors in London. I asked him to write an article for the journal. He had read the minutes and was indeed excited about the light they shed on this chapter of New Jersey history. He sent me a letter in the fall of 2005 in which he gave advice about the publication but also stated, "I'm too old to do what I should like to do in this matter, plus I can no longer make my way to Alexander [Library]. How I miss it!!" He died in January 2006 at the age of 89. 
I had asked McCormick to consider contributing to this volume not only because of his expertise and enthusiasm for these documents, but also because he had a long and close association with this journal. He became the associate editor the same year he began his teaching career at Rutgers in the 1947-48 academic year and continued in that role until 1957. From 1976 to 1983 , he served on the editorial board. He also contributed fourteen articles or notes to the content of this publication between 1947 and 2000. Many of these contributions described primary sources held in Rutgers' Special Collections related to New Jersey history. McCormick's typical article would sketch out the historical context and significance of the item and often contained a transcription or reproduction of the document. His sketches reveal his enthusiasm for the bits and pieces of historical documentation that are the building blocks of historical narratives and insights. As Michael Birkner recognized, "McCormick once observed that his true satisfaction as a historian lay primarily in the 'discovery' phase-working with documents and other primary sources and seeking meaningful patterns in the evidence he was sifting." ${ }^{5}$

A bibliography of his contributions to The Journal of the Rutgers University Libraries follows in chronological order:

"The First Steam Engine in America" 11, 1 (December 1947): 16-20.

An introduction and transcription of a 23 July 1768 letter by Josiah Hornblower about a steam engine used in a mine in Second River [now North Arlington], New Jersey.

"The Jersey Gazette" 13, 1 (December 1949): 31.

An announcement of the beginning of the publication of the Jersey Gazette: A News-Letter of New Jersey Historians.

"New Jersey Defies the Confederation: An Abraham Clark Letter" 13, 2 (June 1950): 44-50.

An introduction and transcription of a 9 December 1785 letter expressing New Jersey's opposition to the financial 
practices of the Continental Congress.

"A Swedish Contribution to New Jersey Historiography" (in Notes from the Library section) 13, 2 (June 1950): 60-61.

Notification of a new acquisition of Special Collections, Israel Acrelius's Description of the Former and Present Condition of the Swedish Churches in What Was Called New Sweden, Afterwards New Netherlands, But at the Present Time Pennsylvania with Adjacent Places in the De La Ware, West Jersey, and New Castle County, in North America (Stockholm, 1759).

"Political Essays of William Paterson" 18, 2 (June 1955): 38-49.

Introduction and reprint of five essays by William Paterson (1745-1793).

"'The Unanimous State'" 23, 1 (December 1955): 4-7.

An account of the unanimous and early ratification of the Constitution of the United States in New Jersey and New Jersey being the first state to appoint delegates to the Constitutional Convention.

"Rutgers and the Civil War" 24, 2 (April 1961): 40-45.

Description of the Civil War years at Rutgers College, from President Theodore Frelinghuysen's rousing call to students in May 1861 to enlist in the great cause to Lincoln's assassination and funeral. Twenty-five students and fifty-eight alumni answered the call. Enrollments plunged from their peak of 124 in May 1861 to as low as sixty-four. For those who stayed at the College, the war did not affect them greatly but the College witnessed a transformation during the war years. It cut its ties to the New Brunswick Theological Seminary, established the new Scientific School and received land-grant designation.

“Poor Slavish Dependents" 28, 1 (December 1964): 1-5.

Description of a recent acquisition of a pamphlet, Amicus Patriae, Proposal for traffick and commerce, or Foreign Trade in 
New-Jersey (1718) concerning how to achieve freedom from the "slavish dependence" of New Jersey on New York by developing foreign trade independent of its larger rival.

"'A Further Account . . ." 34, 2 (June 1971): 33-41.

An introduction to a pamphlet published in London in 1676 and acquired by Special Collections, A Further Account of New Jersey in an Abstract of Letters lately Writ from Thence, describing the difficulties of establishing colonies in the New World.

"The Liberation of New Brunswick: An Anthony Wayne Letter" 37, 1 (December 1973): 10-18.

An introduction and transcript of the 30 June 1777 Wayne letter detailing the British forces' complete withdrawal from New Brunswick in June, 1777.

"Alexander Johnston: An Appreciation" 47, 1 (June 1985): $12-22$.

An appreciation of the scholarship of Alexander Johnston, a Rutgers 1870 graduate and professor of Jurisprudence and Political Economy at the College of New Jersey [Princeton].

"Sir Moses Finley" 49, 2 (December 1986): 63-64.

An obituary for Sir Moses Finley (1912-1986). A distinguished scholar of ancient history at Oxford and Cambridge, Finley also held a unique place in the history of Rutgers and U.S. universities. He was the first professor to be fired from a university because of his refusal to answer questions put to him by the Senate Internal Security Committee during the McCarthy era. He was fired from the department of history in the Newark College of Arts and Sciences of Rutgers University in 1952.

"Rutgers in World War II" 58 (1997): 1-10.

An article on the impact of World War II on Rutgers and higher education in general. 
"Democracy Works in New Jersey" 59 (2000): 19-24. http:// jrul.libraries.rutgers.edu/index.php/jrul/article/view/11/32

A reprint of an article first published in Rutgers Alumni Monthly (October 1947) describing the 1947 New Jersey Constitutional Convention held at Rutgers during the summer months of 1947. The article was part of a special edition of the journal: "New Jersey's Three Constitutions: Essays and Text."

\section{Notes}

1. Richard P. McCormick, New Jersey from Colony to State, 16091789 Princeton, New Jersey: D. Van Norstrand, 1964), 3132.

2. Richard P. McCormick, "Remarks - Morven, 9/27/05" in The Richard P. McCormick Papers (R-MC 050), Special Collections and University Archives, Rutgers University Libraries.

3. Michael J. Birkner, McCormick of Rutgers: Scholar, Teacher, Public Historian (Westport, Connecticut: Greenwood Press, 2001), 13.

4. Richard P. McCormick, Microfilm Report of Dr. Richard P. McCormick: Visit to Great Britain (Trenton, New Jersey: New Jersey Tercentenary Commission, 1960). The resultant 19 microfilm reels can be found in Rutgers' Special Collections and University Archives and other repositories under the title "New Jersey Tercentenary Commission New Jersey Records 17--1962."

5. Birkner, 14 . 